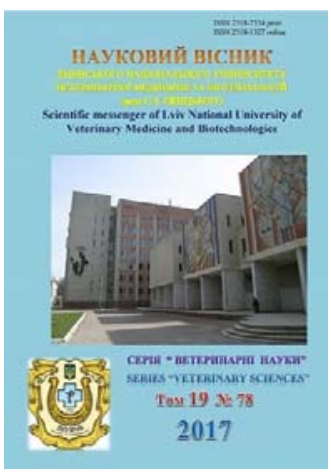

Науковий вісник Львівського національного університету ветеринарної медицини та біотехнологій імені С.З. Гжицького

Scientific Messenger of Lviv National University of Veterinary Medicine and Biotechnologies

doi:10.15421/nvlvet7834

ISSN 2518-7554 print

ISSN 2518-1327 online

$\underline{\text { http://nvlvet.com.ua/ }}$

УДК 636.7:591.482

\title{
Мікроскопічна будова та морфометричні показники грудної і поперекової частин спинного мозку свійського собаки
}

\author{
Л.П. Горальський ${ }^{1}$, І.М. Сокульський ${ }^{1}$ Н.Л. Колеснік ${ }^{1}$, Н.В. Демус ${ }^{2}$ \\ Sokulskiy_1979@ukr.net
}

${ }^{1}$ Житомирський національний агроекологічний університет,

Старий бульвар, 7, м. Житомир, 10002, Украӥна;

${ }^{2}$ Львівський національний університет ветеринарної медицини та біотехнологій імені С.3. Гюсицького, вул. Пекарська, 50, м. Львів, 79010, Україна

\begin{abstract}
У статті за використання морфологічних, нейрогістологічних, морфометричних та статистичних методів досліджень викладено особливості макро- та мікроскопічної будови спинного мозку грудної і поперекової частин статевозрілої собаки. За результатами гістоморфологї встановлена площа і форма поперечного зрізу спинного мозку, остання у грудній частині має круглу форму, у поперековій - овальну. Сіра речовина спинного мозку у вигляді метелика на поперечному зрізі сформована вентральними, дорсальними та латеральними рогами, в яких знаходяться центри симпатичної нервової системи. За результатами наших досліджень у сірій речовині спинного мозку свійської собаки чітко диференціюється власне ядро дорсального рогу, ядро Кларка, латеральне та медіальне проміжні ядра, латеральне та медіальне вентральні ядра.

Згідно проведеної нами гістометрії спинного мозку статевозрілої свійської собаки найбільша площа поперечного зрізу

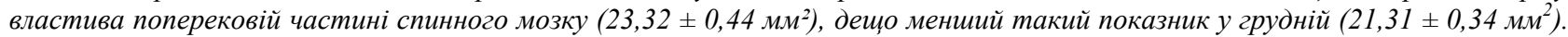
При иьому співвідношення сірої мозкової речовини до білої у поперековій частині становить 1:3,32, щ⿻о в 2 рази менше порівняно з таким показником грудної частини.

Цитопопуляція нервових клітин представлена великими, середніми та малими нейрочитами, щуо в свою чергу, залежать від розміщення їх в певних ділянках сірої речовини спинного мозку: найбільше малих нейронів виявлено у поперековій частині мозку (22,58\%), найменше - у грудній (19,88\%), середніх нейронів найбільше у грудній частині $(44,11 \%)$, найменше - у поперековій $(24,37 \%)$, великих клітин найбільще у поперековій частині $(44,11 \%)$, найменше у грудній $(36,01 \%)$.

Проведені нами иитоморфометричні дослідження свідчать, що нервові клітини сірої речовини спинного мозку статевозрілих собак мають різний об 'єм перикаріонів та їх ядер та відповідно різне ядерно-цитоплазматичне відношення (ЯЦВ), яке є показником функиіональної активності нервових клітин. Найбільший середній об'єм перикаріонів нервових клітин виявлясться у поперековій частині (17723,26 $\pm 816,72$ мкм³), найменший у грудній $\left(12913,53 \pm 915,41\right.$ мкм $\left.{ }^{3}\right)$. Найбільше ядерно-цитоплазматичне відношення виявлено у грудній частині мозку $(0,120 \pm 0,005)$, менше у поперековій $(0,110 \pm 0,004)$.

Ключові слова: статевозріла собака, спинний мозок, сіра речовина спинного мозку, біла речовина спинного мозку, гістологічна будова, морфологічні дослідження, нейрони, нейрочити, ядро, ядерие, ядерно-иитоплазматичне відношення.
\end{abstract}

\section{Микроскопическое строение и морфометрические показатели грудной и поясничной частей спинного мозга домашней собаки}

\author{
Л.П. Горальский ${ }^{1}$, И.Н. Сокульский ${ }^{1}$, Н.Л. Колесник ${ }^{1}$ Н.В. Демус ${ }^{2}$ \\ Sokulskiy_1979@ukr.net
}

${ }^{1}$ Житомирский национальный агроэкологический университет, Старый бульвар, 7, г. Житомир, 10002, Украина;

${ }^{2}$ Львовский национальный университет ветеринарной медицины и биотехнологий имени С.3. Гжицкого,

\section{Citation:}

Horalskyi, L.P., Sokulskyi, I.M., Kolesnik, N.L., Demus, N.V. (2017). Microscopic structure and morphometric parameters of thoratic and lumbar parts of the spinal cord of a domestic dog. Scientific Messenger LNUVMB, 19(78), 167-171. 
В статье за использованием морфологических, нейрогистологических, морфометрических и статистических методов исследований изложены особенности макро- и микроскопического строения спинного мозга грудной и поясничной частей половозрелой собаки. По результатам гистоморфологии установлена площзад и форма поперечного среза спинного мозга, последняя в грудной части имеет круглую форму, в поясничной-овальную. Серое вещество спинного мозга в виде бабочки на поперечном срезе представлено вентральными, дорсальными и латеральными рогами, в которых находятся иентры симпатической нервной системы. По результатам наших исследований в сером веществе спинного мозга домашней собаки четко дифференцируется собственное ядро дорсального рога, ядро Кларка, латеральные и медиальные промежуточные ядра, латеральные и медиальные вентральные ядра.

Согласно проведенной нами гистометрии спинного мозга половозрелой домашней собаки самая большая площадь поперечного среза свойственна поясничной части спинного мозга $\left(23,32 \pm 0,44\right.$ мм² $^{2}$, несколько меньше такой показатель 6 грудной $\left(21,31 \pm 0,34\right.$ мм² $^{2}$. При этом соотношение серого мозгового вещества к белому в поясничной части составляет 1:3,32, что в 2 раза меньше по сравнению с таким показателем грудной части.

Цитопопуляция нервных клеток представлена крупными, средними и мальми нейроцитами, что в свою очередь, зависят от размещения их в определенных участках серого вещества спинного мозга: больше мальх нейронов выявлено в поясничной части мозга (22,58\%), наименьше - в грудной (19,88\%), средних нейронов больще в грудной части (44,11\%), наименьше - в поясничной (24,37\%), крупных клеток больше в поясничной части (44,11\%), меньше - в грудной (36,01\%).

Проведенные нами ичтоморфометрические исследования показывают, что нервные клетки серого вещества спинного мозга половозрелых собак имеют разный объем перикарионов $и$ их ядер и соответственно разное ядерноиитоплазматическое отношение (ЯЦВ), которое является показателем функииональной активности нервных клеток. Наибольший средний объем перикарионов нервных клеток оказывается в поясничной части (17723,26 \pm 816,72 мкм³), наименьший в грудной $(12913,53 \pm 915,41$ мкм³). Больше всего ядерно-иитоплазматическое отношение обнаружено в грудной части мозга $(0,120 \pm 0,005)$, меньше в поясничной $(0,110 \pm 0,004)$.

Ключевые слова: половозрелая собака, спинной мозг, серое вещество спинного мозга, белое вещество спинного мозга, гистологическое строение, морфологические исследования, нейроны, нейрочиты, ядро, ядрышко, ядерноцитоплазматическое отношение.

\title{
Microscopic structure and morphometric parameters of thoratic and lumbar parts of the spinal cord of a domestic dog
}

\author{
L.P. Horalskyi ${ }^{1}$, I.M. Sokulskyi ${ }^{1}$, N.L. Kolesnik ${ }^{1}$, N.V. Demus ${ }^{2}$ \\ Sokulskiy_1979@ukr.net

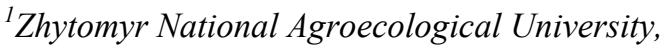 \\ Staryi Boulevard, 7, Zhytomyr, 10002, Ukraine; \\ ${ }^{2}$ Stepan Gzhytskyi National University of Veterinary Medicine and Biotechnologies Lviv, \\ Pekarska Str., 50, Lviv, 79010, Ukraine
}

\begin{abstract}
The article describes the features of the macroscopic and microscopic structure of the spinal cord of the chest and lumbar parts of a mature dog for the use of morphological, neurohistological, morphometric and statistical methods of research. According to the results of histomorphology, the area and shape of the transverse section of the spinal cord is determined, the latter in the thoracic region has a round shape, in the lumbar - oval. Gray substance of the spinal cord in the form of a butterfly on a transverse section is formed by ventral, dorsal and lateral horns, in which are centers of the sympathetic nervous system. According to our research, in the gray matter of the spinal cord of a domestic dog, the core of the dorsal horn, the Clark core, the lateral and medial intermediate nuclei, the lateral and medial ventral nuclei are clearly differentiated.

According to histometry of the spinal cord of the mature dog, conducted by us, the largest cross-sectional area is characteristic of the lumbar spinal cord $\left(23.32 \pm 0.44 \mathrm{~mm}^{2}\right)$, is slightly lower in the breast $(21.31 \pm 0.34 \mathrm{~mm} 2)$. In this case, the ratio of gray cerebrospinal fluid to white in the lumbar part is 1: 3.32, which is 2 times less in comparison with the such indicator of the thoratic part.

The cytopupulation of the nerve cells is represented by large, medium and small neurocytes, which, in its turn, depend on their placement in certain areas of the gray matter of the spinal cord: the most small neurons are found in the lumbar part of the cord $(22.58 \%)$, the least are in the thoracic (19.88\%), medium neurons are the highest in the thoracic part (44.11\%), the least are in the lumbar (24.37\%), the largest cells are in the lumbar part (44.11\%), the least are in the thoracic (36.01\%).

Our cytomorphometric studies indicate that the nerve cells of the gray matter of the spinal cord of mature dogs have a different volume of pericarions and their nuclei and, accordingly, a different nuclear-cytoplasmic ratio (NCR), which is an indicator of the functional activity of nerve cells. The largest average volume of pericarios of nerve cells is found in the lumbar part (17723.26 \pm $\left.816.72 \mathrm{mcm}^{3}\right)$, the smallest are in the chest $\left(12913.53 \pm 915.41 \mathrm{mcm}^{3}\right)$. The largest nuclear-cytoplasmic ratio was found in the thoracic part of the cord $(0.120 \pm 0.005)$, less are in the lumbar $(0.110 \pm 0.004)$.
\end{abstract}

Key words: mature dog, spinal cord, gray matter of the spinal cord, white matter of the spinal cord, histological structure, morphological research, neurons, neurocytes, nucleus, nucleolus, nuclear-cytoplasmic ratio.

\section{Вступ}

Актуальним питанням, щодо закономірностей розвитку, будови і функціонування організму людини і тварин є усестороннє, комплексне вивчення складу і структурно-функціональних особливостей нервової системи вищих організмів (Zherebcov, 1991). 
Слід зазначити, що нервова система посідає найвагоміше місце в регуляції всіх процесів життєдіяльності організму (Horalskyi et al., 2016). Як показали дослідження останніх років структурно-функціональна організація центральної нервової системи складається 3 нейронів і гліоцитів, що визначає морфологічну гетерогенність нервової тканини.

Особливий інтерес до нервової системи зумовлений іiі різноманітними функціями і властивостями: сприйняттям та проведенням нервових імпульсів, трансформацією, генерацією, зберіганням різних видів енергії й інформації зовнішнього середовища, а також іiі здатністю до збудження, гальмування, до процесів синтетичного та аналітичного порядку, трофічної функції (Pisaleva, 2012; Horalskyi et al., 2016).

Актуальність теми. Дослідженнями авторів відмічено, що у макро- та мікроморфології спинного мозку хребетних тварин встановлені характерні видові відмінності (Horalskyi et al., 2015; Horalskyi et al., 2016). На сьогоднішній день актуальним питанням лишається вивчення якісних і кількісних змін органів нервової системи. Сучасний рівень нейроморфології вимагає більш глибокого знання функціональної значимості окремих компонентів нервової тканини: нервових клітин, гліальних елементів тощо, у першу чергу для характеристики нормальних або патологічних нервових процесів (Rubinow and Marisa, 2009; Pisaleva, 2012). Проте, видова морфологія нервової системи, в тому числі спинного мозку хребетних тварин, на даний час, висвітлена ще недостатньо.

Результати даного дослідження мають важливе загальнобіологічне значення, оскільки дозволяють дати більш об'єктивну кількісну оцінку структурам органів нервової системи.

Метою наших досліджень було з'ясувати морфологічну характеристику та морфометричні показники грудної і поперекової частин спинного мозку статевозрілих свійських собак. Для досягнення цієї мети були поставлені такі завдання:

- з'ясувати морфологічні особливості спинного мозку статевозрілих собак у порівняльноанатомічному ряді;

- встановити форму і площу поперечного зрізу грудної і поперекової частин спинного мозку і площу в них сірої та білої речовин;

- з'ясувати закономірності мікроструктурної організації відповідних частин спинного мозку;

- провести морфометричний аналіз нейроцитів (об’єм перикаріонів, об'єм ядер, ядерноцитоплазматичне відношення) відповідних частин спинного мозку.

\section{Матеріал і методи досліджень}

Дослідження виконувались на кафедрі анатомії і гістології факультету ветеринарної медицини Житомирського національного агроекологічного університету.

Матеріалом для гістологічних дослідження був спинний мозок статевозрілих свійських собак (Sus scrofa, forma domestica) масою тіла 20-30 кг та висотою в холці 40-49 см $(\mathrm{n}=6)$. В роботі використовува- лись анатомічні, гістологічні, нейрогістологічні, морфометричні, і статистичні методи досліджень (Ноralskyi et al., 2011). Для гістологічного дослідження шматочки матеріалу фіксували в $10 \%$ водному розчині нейтрального формаліну, з наступною заливкою в парафін, після чого виготовляли серійні зрізи, які фарбували гематоксиліном та еозином. Нейрофібрилярний апарат у нервових клітин виявляли за допомогою нейрогістологічніх методів досліджень (імпрегнація сріблом за методом Більшовський-Грос, тотальна імпрегнація за Рамон-і-Кахалем) з використанням рекомендацій, які запропоновані у посібнику Л.П. Горальського, О.I. Кононського (Horalskyi et al., 2011). Морфометричні дослідження гістологічних препаратів здійснювали за допомогою мікроскопів «Біолам-Ломо» та МБС-10. Мікрофотографування частини цих препаратів здійснювали за допомогою мікроскопа Micros MC-50 і вмонтованою у нього відеокамерою CAM V200, підключеною до персонального комп'ютера, а також мікроскопа МБС-10 із цифровою фотокамерою «Сanon».

\section{Результати та їх обговорення}

Поперечний зріз грудної частини спинного мозку набуває майже круглої форми. Сіра речовина спинного мозку на поперечному зрізі має вигляд метелика i складається із вентральних та дорсальних рогів (рис. 1). Вентральні роги у цій частині мозку, мають форму прямокутника. Дорсальні - тонкі. Проміжна центральна речовина і центральний канал виражені слабо. Проміжна латеральна речовина випинається і утворює латеральні роги, в яких, як відомо, знаходяться центри симпатичної нервової системи.

Морфометричними дослідженнями встановлено, що площа поперечного зрізу грудної частини спинно-

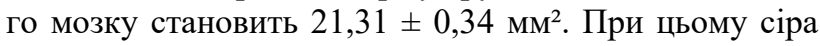
мозкова речовина займає $13,15 \pm 0,27 \% \quad(2,79 \pm$

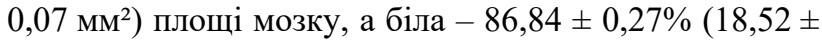
$0,31 \mathrm{мм}^{2}$ ). Відношення сірої речовини до білої становить $1: 6,63$.

Нервові клітини у сірій мозковій речовині відрізняються між собою за формою та розмірами. Серед них виявляються малі, середні та великі нейрони. Великі нейрони сірої речовини, які мають, переважно, зірчасту та багатогранну форму з вираженими відростками, знаходяться на периферії сірої мозкової речовини. Крім таких, виділяють середні нейрони овальної, багатогранної або продовгуватої форми, які розміщуються частіше поодиноко, рідше групами по 24 клітини, у середній частині вентрального рогу та біля великих нервових клітин. Водночас трапляються малі нервові клітини неправильної або ж витягнутої форми з чітко вираженими відростками, які розміщуються поодиноко по всій площі вентрального рогу.

Найбільше нейроцитів виявляється у вентральних рогах, потім у латеральних та дорсальних.

Дорсальні роги грудної частини спинного мозку представлені, в більшості, малими нейронами з ледь помітними відростками.

В досліджуваних сегментах грудної частини добре виражене ядро Кларка, котре являє собою округлу 
групу клітин. Дане ядро представлене 5-6 клітинами середнього розміру, які мають овальну або округлу форму.

Латеральні роги представлені, у більшості, великими нейроцитами, які формують симпатичне ядро латерального рогу. Такі клітини, в основному, багатогранної форми.

Великі мотонейрони, які мають, в більшості, зірчасту, багатогранну форми та виражене велике ядро, розміщені по 2-3 клітини. Таке скупчення нейронів 3 великою кількістю відростків утворює ядра вентрального рогу, які розділяються на латеральні, центральні і медіальні. Так, наприклад, латеральні ядра вентральних рогів представлені 6-8 нейронами, серед них 45 великих мультиполярних нейрона. Інші клітини середнього розміру блідо зафарбовані, неправильноокруглої або грушеподібної форми. Медіальні ядра

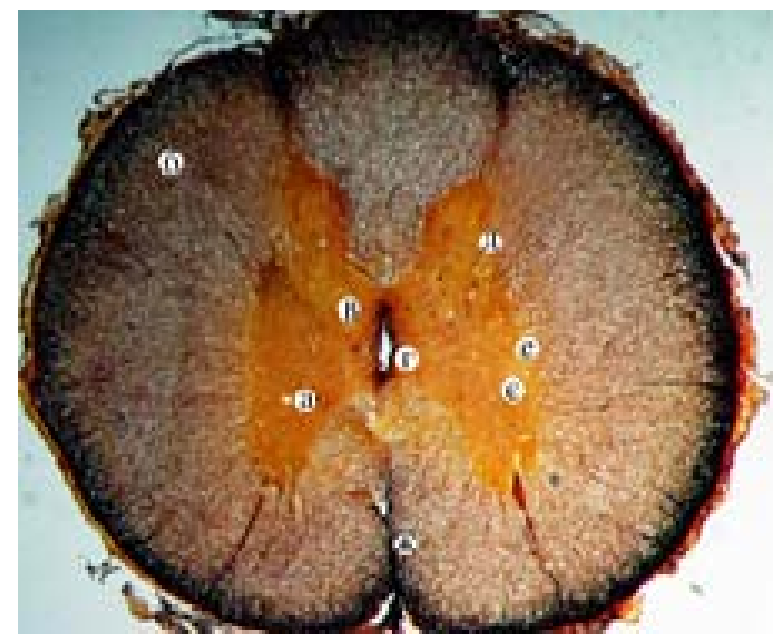

Рис. 1. Поперечний зріз грудної частини спинного мозку свійського собаки: a - сіра речовина; $б$ - біла речовина; в - сіра спайка; г - центральний канал; д - дорсальні роги; е - латеральні роги; $\epsilon$ - вентральні роги; ж-вентральна серединна щілина.

Рамон-і-Кахаль. $\times 32$

Площа поперечного зрізу поперекової частини спинного мозку, у порівнянні з грудною частиною збільшується i на поперечному розрізі має форму овалу (рис. 2). Роги сірої речовини більш об'ємні, ніж в грудній частині. Дорсальні роги крилоподібні, а вентральні - овально-видовжені. Центральна проміжна речовина i центральний канал добре виражені. Добре виражена і латеральна проміжна речовина. Їі випини, які в грудній частині утворюють латеральні роги сферичної форми.

У поперековій частині порівняно 3 попередньою частиною, спостерігається достовірне збільшення у $1,1$ рази (Р $<0,001)$ площі поперечного зрізу спинного

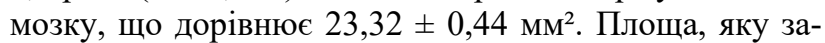
ймає сіра речовина на зрізі збільшується в 2 рази в порівнянні з грудною частиною. При цьому відсоток сірої мозкової речовини складає $23,11 \pm 0,52 \%$

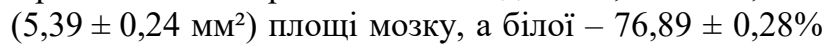

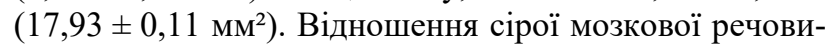
ни до білої складає $1: 3,32$, що в 2 рази менше порівняно з грудною частиною. вентральних рогів представлені 5-6 нейронами великих розмірів багатогранної форми. Крім того відмічається поява біля них малих (5-6) округлої і овальної форми клітин 3 вираженими відростками. Останні виявляються в медіальних і латеральних ядрах вентрального рогу, а також на периферії.

Нейропопуляція у сірій речовині спинного мозку представлена різними за величиною нервовими клітинами. Найбільше $(44,11 \%)$ виявлено середніх клітин, потім - великих (36,01\%) та малих (19,88\%).

Результати морфометричних досліджень свідчать, що середній об'єм нервових клітин дорівнює $12913,53 \pm 915,41$ мкм³. Середній об’єм ядра $839,92 \pm 59,54$ мкм $^{3}$. Середнє ядерно-цитоплазматичне відношення складає $0,120 \pm 0,005$.

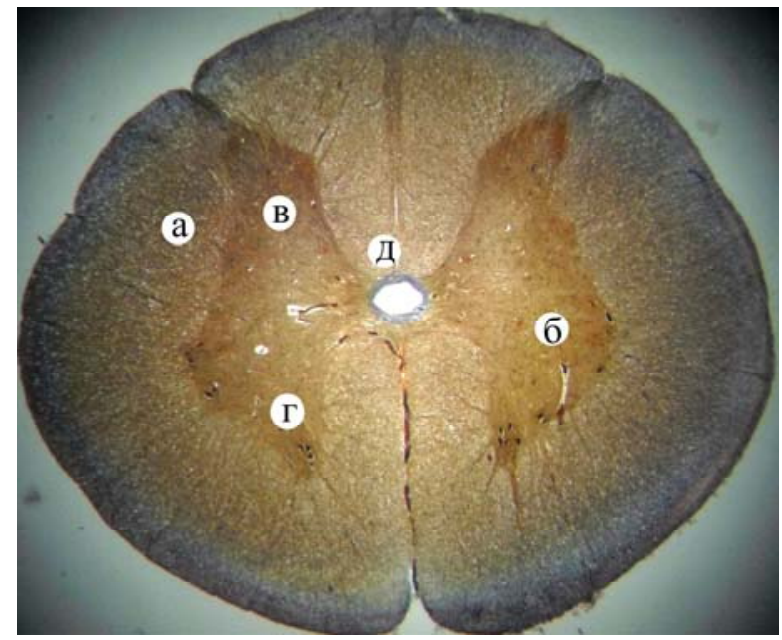

Рис. 2. Поперечний зріз поперекової частини спинного мозку свійського собаки: а - біла речовина, б - сіра речовина, в - дорсальний ріг сірої речовини; г - вентральний ріг; д - спинномозковий канал. Гематоксилін та еозин. $\times 32$.

У дорсальних рогах міститься значна кількість малих та середніх мультиполярних нейронів (рис. 3). Більшість таких клітин мають овальну, округлу форму $з$ вираженими ядрами. Також трапляються нейрони видовженої форми, їх ядра набувають форми перикаріону. Власне ядро дорсального рогу утворюють 67 середніх та малих нейрони багатогранної та овальної форми з вираженими чіткими відростками. Ядра таких нервових клітин розміщені центрично.

Вентральний ріг сірої речовини утворюють дві групи ядер - латеральні та медіальні (рис. 4). На поперечних зрізах поперекової частини спинного мозку в медіальному ядрі виділяється 10-12 великих нейронів 3 розмірами від 60-70 мкм по довжині та 4046 мкм по ширині. Латеральне ядро представлене $12-$ 14 великими мультиполярними клітинами пірамідної або зірчастої форми, які мають найбільший об’єм у порівнянні 3 іншими клітинами сірої речовини (до 76159,72 мкм³).

Проведені нами морфометричні дослідження свідчать, що нейрони сірої речовини поперекової частини 
спинного мозку мають різні розміри. При цьому, найбільша кількість нервових клітин представлена великими клітинами $(53,05 \%)$, на другому місці - середні

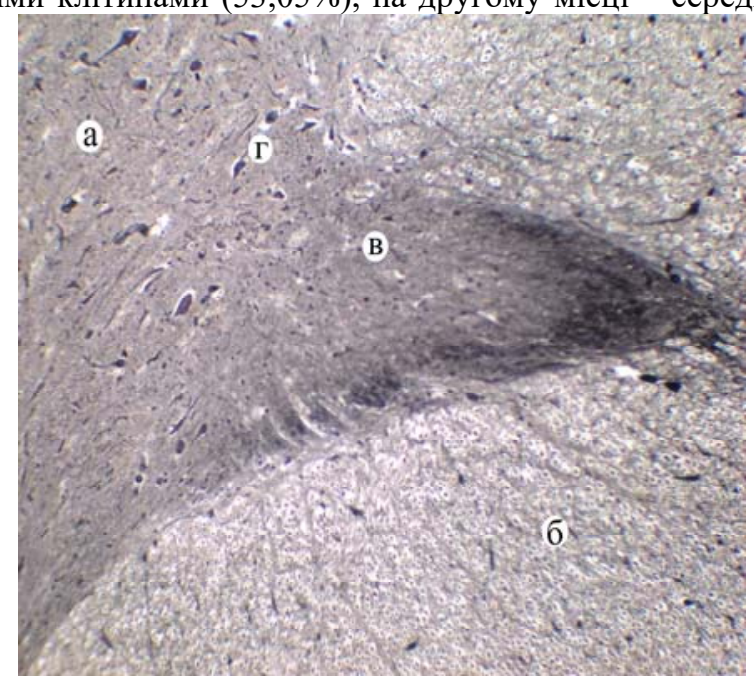

Рис. 3. Мікроскопічна будова дорсального рогу поперекової частини спинного мозку свійського собаки: а - сіра речовина; б - біла речовина; в - дорсальний ріг; г - нейрони. Більшовський-Грос. $\times 80$.

У поперековій частині спинного мозку відмічається тенденція до збільшення об’ємів усіх груп нейронів, по відношенню до попередньої частини, а таким чином і середнього значення цих показників. Так, середній об'єм перикаріонів нервових клітин збільшується у 1,4 рази $(\mathrm{P}<0,001)$ відносно грудної частини $\left(17723,26 \pm 816,72\right.$ мкм $\left.^{3}\right)$, а середнє значення об'єму ядра у 1,3 рази $(\mathrm{P}<0,001)(1070,81 \pm$ 41,48 мкм³). Проте, на відміну від грудної частини спинного мозку, у поперековій його частині паралельно із зростанням показників об'ємів їх перикаріонів та ядер, відмічається зменшення ЯЦВ, яке становить $0,110 \pm 0,004(\mathrm{P}<0,05)$.

\section{Висновки}

В різних частинах спинного мозку статевозрілих собак відмічаються різні показники площі та форма їх поперечного зрізу. Остання у грудній частини має майже круглу форму, у поперековій - овальну. Найбільша площа поперечного зрізу властива поперековій частині спинного мозку $\left(23,32 \pm 0,44\right.$ мм²$\left.^{2}\right)$, дещо менший цей показник у грудній $\left(21,31 \pm 0,34\right.$ мм² $^{2}$. Характерні відмінності гістоструктур спинного мозку (відсоткове співвідношення сірої речовини до білої) грудної і поперекової частин собаки проявляються вираженою диференціацію нервових клітин, які мають різну форму і розміри, і відповідно різне ядерноцитоплазматичне відношення, яке залежить від морфофункціонального стану нервових клітин та відповідного відділу нейросегменту.

Перспективи подальших досліджень передбачають по-перше провести гістохімічні дослідження відповідних частин спинного мозку. По-друге, напрямок досліджень повинен бути направлений на прове- нейрони $(24,37 \%)$, і найменшу кількість популяції становлять малі клітини (22,58\%).

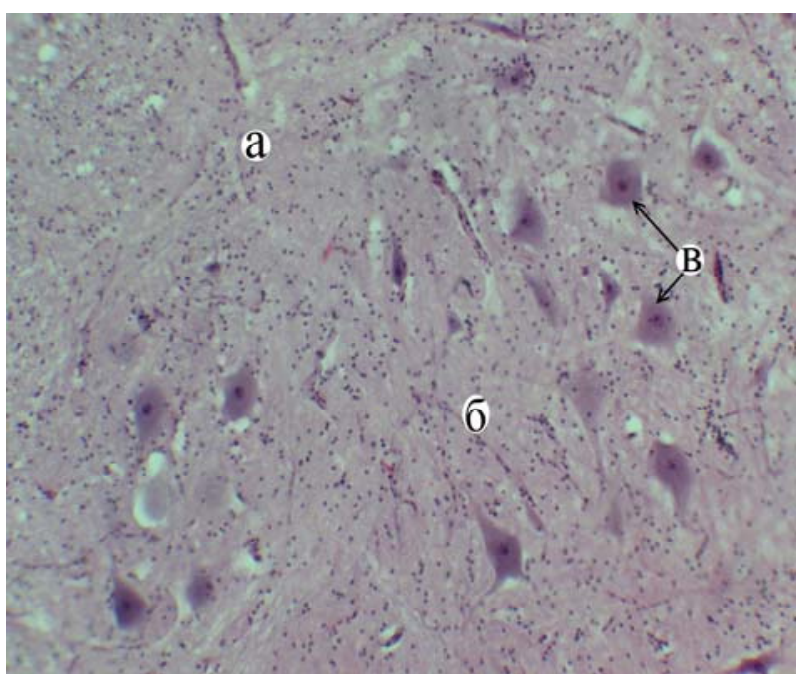

Рис. 4. Мікроскопічна будова вентрального рогу поперекової частини спинного мозку свійського

собаки: a - сіра речовина; б - латеральне ядро вентрального рогу; в - нервові клітини.

Гематоксилін та еозин. $\times 100$.

дення ультраструктурної будови спинного мозку статевозрілих собак.

\section{Бібліографічні посилання}

Horalskyi, L.P., Khomych, V.T., Kononskyi, O.I. (2011). Osnovy histolohichnoi tekhniky i morfofunktsionalni metody doslidzhennia u normi ta pry patolohii: navch. Posibnyk. Zhytomyr: Polissia (in Ukrainian).

Zherebcov, N.A. (1991). Obshhie zakonomernosti postnatal'nogo morfogeneza nejrocitov i nervnyh volokon $\mathrm{u}$ domashnih zhivotnyh. Morfo-jekologicheskie problemy v zhivotnovodstve i veterinarii: materialy dokl. Resp. nauch. konf. Morfologov. K., 35-36 (in Russian).

Pisaleva, S.G. (2012). Morfometricheskaja harakteristika spinnogo mozga besporodnyh sobak $\mathrm{v}$ rannem postnatal'nom ontogeneze: avtoref. dis. na soiskanie uchen. stepeni kand. vet. nauk: 06.02.01. Saransk, 20 (in Russian).

Horalskyi, L.P., Sokulskyi, I.M., Veremchuk, Ya.Yu. (2015). Morfolohiia mozochka, spynnoho mozku ta spynnomozkovykh vuzliv u sviiskykh tvaryn. Nauk. visn. Nats. un-tu bioresursiv i pryrodokorystuvannia Ukrainy. Ser. Vet. medytsyna, yakist i bezpeka produktsii tvarynnytstva. 227, 62-66 (in Ukrainian).

Horalskyi, L.P., Khomych, V.T., Sokulskyi, I.M. (2016). Morfolohiia spynnoho mozku ta spynnomozkovykh vuzliv khrebetnykh tvaryn : monohr., vyd 2-he, dop. Lviv : ZUKTs (in Ukrainian).

Rubinow, M.J., Marisa, J.M. (2009). Neuron and glia number in the basolateral nucleus of the amygdala from prewraning through old age in male and female rats: a stereological study. The journal of comparative neurology. 512(6), 717-725. 